\title{
DESTRUCTION OF BIOFILMS UNDER ACTION OF SURFACTANTS SYNTHESIZED BY NOCARDIA VACCINII IMV B-7405 ON WASTE OF BIODIESEL PRODUCTION
}

\author{
T. Pirog, L. Nikitiuk, K. Kondrashevska, I. Kluchka \\ National University of Food Technologies
}

\begin{tabular}{l}
\multicolumn{1}{c}{ Key words: } \\
Nocardia vaccinii IMV \\
B-7405 \\
Industrial waste \\
Surfactants \\
Biofilm disruption \\
\hline
\end{tabular}

Article history:

Received 09.11.2018

Received in revised form

23.11.2018

Accepted 18.12.2018

Corresponding author:

T. Pirog

E-mail:

npnuht@ukr.net

\begin{abstract}
Nowadays, the research of safe and effective compounds that would prevent the adhesion of microorganisms to surfaces, or destroy biofilm on various surfaces remains relevant. About $65-80 \%$ of all infectious diseases are caused by bacteria that form biofilms on the surface of medical implanted equipment (lenses, catheters, prostheses, artificial heart valves) or in food industry. Modern technologies of destruction of microbial biofilms involve the use of mechanical, physical, chemical and biological methods. In recent years, biological methods have been favored due to their high efficiency, prolonged action and safety for humans and the environment.

In the article the effect on disruption of bacterial and yeast biofilms of surfactants synthesized by Nocardia vaccinii IMV B-7405 on purified glycerol and waste biodiesel production was compared. The dependence of biofilms destruction under action of $N$. vaccinii IMV B-7405 surfactants on degree of glycerol purification, duration of producer cultivation, surfactant concentration and type of test culture was established. Increasing duration of IMV B-7405 cultivation from 5 to 7 days on purified glycerol was accompanied by synthesis of surfactants, in the presence of which destruction of biofilms of Bacillus subtilis BT-2, Pseudomonas sp. M-2 and Candida albicans D-6 declined. At the same time, disruption of biofilms under action of surfactants (140 $280 \mu \mathrm{g} / \mathrm{ml}$ ), synthesized during 7 days on waste biodiesel production, was $11-15 \%$ higher than in presence of preparations obtaining on this substrate during 5 days.

Replacing purified glycerol with waste of biodiesel production for $N$. vaccinii IMV B-7405 cultivation allows to dispose toxic waste, reduce cost of surfactants and obtain the final product with high anti-adhesive activity.
\end{abstract}

DOI: $10.24263 / 2225-2924-2018-24-6-8$ 


\title{
РУЙНУВАННЯ БІОПЛІВОК ЗА ДІЇ ПОВЕРХНЕВО- АКТИВНИХ РЕЧОВИН, СИНТЕЗОВАНИХ NOCARDIA VACCINII ІМВ В-7405 НА ВІДХОДАХ ВИРОБНИЦТВА БІОДИЗЕЛЮ
}

\author{
Т.П. Пирог, Л.В. Никитюк, К.Р. Кондрашевська, І.В. Ключка \\ Національний університет харчових технологій
}

Нині актуальним залишається пошук безпечних та ефективних сполук, які б перешкоджали адгезії мікроорганізмів до поверхонь або ж руйнували вже існуючої біоплівки на різноманітних поверхнях. Серед усіх інфекційних захворювань близько 65-80\% спричиняються бактеріями, які формують біоплівки на поверхні медичного імплантованого обладнання (лінзи, катетери, протези, итучні серцеві клапани) або харчової промисловості. Сучасні технології руйнування мікробних біоплівок передбачають використання механічних, фізичних, хімічних і біологічних методів. В останні роки перевага надається біологічним методам завдяки їх високій ефективності, пролонгованій дії, безпечності для людини і навколищнього середовища.

У статті порівняно вплив на руйнування бактеріальних $і$ дріжджових біоплівок поверхнево-активних (ПАР), синтезованих Nocardia vaccinii IMB B-7405 на очищеному гліцерині і відходах виробництва біодизелю. Встановлено залежність ступеня руйнування біоплівок під впливом ПАР N. vaccinii IMB B-7405 від ступеня очищення глічерину, тривалості культивування продуцента, концентрації ПАР у препаратах та типу тест-культури. Збільшення тривалості культивування штаму IMB B-7405 з 5 до 7 діб на очищеному глічерині супроводжувалося синтезом поверхнево-активних речовин, за наявності яких ступінь руйнування біоплівок Bacillus subtilis БT-2, Pseudomonas sp. M-2 i Candida albicans Д-6 знижувався. У той же час деструкиія біоплівок за дії ПАР (140-280 мкг/мл), синтезованих упродовж 7 діб на відходах виробництва біодизелю, була на 11-15\% вищзю, ніж за наявності поверхневоактивних речовин, утворених на иььому субстраті упродовж 5 діб.

Заміна очищеного глічерину на відходи виробництва біодизелю у середовищі культивування $N$. vaccinii IMB B-7405 дає змогу утилізувати токсичні відходи, знизити собівартість ПАР і отримати ияільовий продукт з високою антиадгезивною активністю.

Ключові слова: Nocardia vaccinii IMB B-7405, промислові відходи, поверхнево-активні речовини, деструкція біоплівки.

Постановка проблеми. Бактерії здатні адгезуватися на поверхні різних матеріалів і формувати біоплівку, небезпека утворення якої полягає в тому, що прикріплені мікробні клітини набувають резистентності до антимікробних препаратів [1-3]. Пошук безпечних та ефективних засобів, які б перешкоджали адгезії мікроорганізмів до різноманітних поверхонь або ж руйнували архітектуру вже існуючої біоплівки, є актуальним, оскільки колонізація 
бактеріями імплантатів, катетерів та інших медичних поверхонь призводить до інфікування пацієнтів 3 летальними випадками. Біоплівкоутворення на робочих поверхнях обладнання у харчовій промисловості спричиняє псування готової продукції.

Нині відомо багато способів руйнування мікробних біоплівок, зокрема застосування неорганічних сполук, хімічних препаратів, антибіотиків та бактеріофагової терапії [3]. Проте виникнення у мікроорганізмів резистентності до антибіотиків та інших біоцидів, дорожнеча багатьох методів запобігання утворенню та руйнуванню біоплівок стимулювала пошук нових речовин з відповідними властивостями.

Мікробні ПАР розглядаються як альтернативна заміна хімічно-синтезованих речовин, тому що їм притаманні ряд переваг (біодеградабельність, нетоксичність, стабільні фізико-хімічні властивості, низький ризик появи резистентних мікроорганізмів) [4].

Проте практичне використання мікробних ПАР обмежується їх високою собівартістю. Здешевлення технології виробництва цільового продукту можна досягти культивуванням штаму-продуцента на промислових відходах, зокрема відходах виробництва біодизелю, зберігання яких $є$ потенційною екологічною проблемою через підвищену лужність, вміст залишків токсичного метанолу, високої концентрацій солей і вільних жирних кислот [5].

Раніше [6] нами було показано, що поверхнево-активні речовини, синтезовані за умов росту Nocardia vaccinii IMB B-7405 на очищеному гліцерині, характеризувалися високою здатністю до руйнування біоплівки Escherichia coli IEM-1 на полістиролі (ступінь руйнування близько 80\%).

У [7] ми встановили можливість інтенсифікації синтезу ПАР $N$. vaccinii IMB B-7405 на відходах виробництва біодизелю, одержаних безпосередньо від заводу-виробника. Разом з тим наші попередні дані [8] засвідчують, що не завжди підвищення синтезу ПАР супроводжується утворенням цільового продукту з необхідними біологічними властивостями, що потребує проведення досліджень залежності властивостей поверхнево-активних речовин від умов культивування продуцента.

Мета статті: порівняння впливу на руйнування бактеріальних і дріжджових біоплівок поверхнево-активних (ПАР), синтезованих $N$. vaccinii IMB B-7405 на очищеному гліцерині і відходах виробництва біодизелю.

Матеріали і методи. Об'єкт дослідження - ізольований нами із забрудненого нафтою грунту штам нафтоокиснювальних бактерій, ідентифікований як Nocardia vaccinii K-8 та зареєстрований в Депозитарії мікроорганізмів Інституту мікробіології і вірусології ім. Д.К. Заболотного Національної академії наук України за номером IMB B-7405.

Як тест-культури для утворення біоплівки використовували бактерії Bacillus subtilis БТ-2, Escherichia coli IEM-1, Pseudomonas sp. М-2 і дріжджі Candida albicans Д-6 з колекції живих культур кафедри біотехнології і мікробіології Національного університету харчових технологій.

$N$. vaccinii IMB В-7405 вирощували в колбах на качалці (320 об/хв) при $30^{\circ} \mathrm{C}$ упродовж 5-7 діб в рідкому мінеральному середовищі такого складу (г/л): $\mathrm{NaNO}_{3}-0,5 ; \mathrm{MgSO}_{4} \times 7 \mathrm{H}_{2} \mathrm{O}-0,1 ; \mathrm{CaCl}_{2}-0,1 ; \mathrm{KH}_{2} \mathrm{PO}_{4}-0,1$; 
$\mathrm{FeSO}_{4} \times 7 \mathrm{H}_{2} \mathrm{O}-0,001$, дріжджовий автолізат $-0,5 \%$ (об'ємна частка). Як джерело вуглецю використовували очищений гліцерин у концентрації $2 \%$ (об'ємна частка), а також відходи виробництва біодизелю (Комсомольський біопаливний завод, Полтавська обл.) (2\%, об’ємна частка).

Як посівний матеріал використовували культуру в експоненційній фазі, вирощену на середовищі наведеного складу з $0,5 \%$ відповідного субстрату. Інокулят, в якому чисельність бактерій становила $10^{4}-10^{5}$ кл/мл, вносили у кількості 10\% від об'єму середовища.

Кількість синтезованих позаклітинних ПАР (г/л) визначали ваговим методом після екстракції з супернатанту культуральної рідини, модифікованою сумішшю Фолча. Для отримання супернатанту культуральну рідину центрифугували при $5000 \mathrm{~g}$ протягом 20 хв. Виділення позаклітинних ПАР здійснювали, як описано нижче.

У циліндричну ділильну лійку об'ємом 500 мл поміщали 100 мл супернатанту, додавали 20 мл $1 \mathrm{M}$ розчину $\mathrm{HCl}$, воронку закривали шліфованою пробкою і струшували 3 хв, потім додавали ще 15 мл $1 \mathrm{M}$ розчину $\mathrm{HCl}$ і 65 мл суміші хлороформу і метанолу (2:1) і струшували (екстрагування ліпідів) протягом 5 хв. Отриману після екстракції суміш залишали в ділильній воронці для поділу фаз, після чого нижню фракцію зливали (органічний екстракт 1), а водну фазу піддавали повторній екстракції. При повторній екстракції до водної фази додавали 35 мл $1 \mathrm{M}$ розчину $\mathrm{HCl}$ і 65 мл суміші хлороформу i метанолу (2:1) й екстрагували ліпіди протягом 5 хв. Після поділу фаз зливали нижню фракцію, отримуючи органічний екстракт 2. На третьому етапі до водної фази додавали 100 мл суміші хлороформу і метанолу $(2: 1)$ і здійснювали екстракцію, як описано вище, отримуючи органічний екстракт 3. Екстракти $1-3$ об'єднували й упарювали на роторному випарнику IP-1M2 (Росія) при $50^{\circ} \mathrm{C}$ і абсолютному тиску 0,4 атм до постійної маси. Всі препарати стерилізували при $112^{\circ} \mathrm{C}$ протягом 30 хв.

У дослідженнях використовували препарати ПАР $N$. vaccinii IMB B-7405 різного ступеня очищення:

nрепарат 1 - супернатант культуральної рідини, для одержання якого постферментаційну культуральну рідину центрифугували упродовж 45 хв $(5000 \mathrm{~g})$ для осадження біомаси;

nрепарат 2 - розчин ПАР, виділених з супернатанту (препарат 1) екстракцією сумішшю Фолча, як кописано вище. Сухий залишок ПАР перерозчиняли в стерильному фосфатному буфері $(0,1 \mathrm{M}, \mathrm{pH} 7,0)$ до вихідного об'єму.

Дослідження впливу ПАР на руйнування біоплівки здійснювали, як описано у [9]. Для формування біоплівки у полістиролові мікропланшети вносили 180 мкл м'ясо-пептонного бульйону (МПБ) для бактерій або рідкого сусла (для дріжджів) та 20 мкл суспензії однодобової тест-культури, інкубували упродовж 24 год при оптимальній для тест-культури температурі, після чого зливали культуральну рідину і вносили 180 мкл свіжого МПБ чи рідкого сусла і 20 мкл суспензії тест-культури і ще інкубували впродовж наступних 24 год. Через 48 год культуральну рідину зливали, а в лунки мікропланшета (з попередньо сформованою на них біоплівкою тест-культури) вносили по 200 мкл препаратів ПАР різної концентрації. У контрольні варіанти (лунки) 
замість препаратів ПАР вносили стерильну водопровідну воду (200 мкл). Через 24 год експозиції лунки тричі промивали 200 мкл дистильованої води і визначали кількість адгезованих клітин спектрофотометричним методом. Ступінь руйнування біоплівки (\%) визначали як різницю між адгезією клітин у необроблених і оброблених ПАР лунках полістиролового планшету.

Всі досліди проводили в трьох повторностях, кількість паралельних визначень в експериментах становило від 3 до 5. Статистичну обробку експериментальних даних проводили, як описано раніше [7]. Відмінності середніх показників вважали достовірними при рівні значущості $p<0,05$.

Результати і обговорення. У [10] нами було встановлено залежність антимікробної активності ПАР $N$. vaccinii IMB В-7405 від тривалості культивування продуцента на різних вуглецевих субстратах. Так, поверхневоактивні речовини, синтезовані упродовж 7 діб на рафінованій і відпрацьованій соняшниковій олії, виявилися ефективнішими антимікробними агентами щодо фітопатогенних бактерій, ніж ПАР, утворювані на 5 добу культивування продуцента на цих субстратах. Збільшення з 5 до 7 діб тривалості вирощування.

$N$. vaccinii IMB B-7405 як на очищеному, так і технічному гліцерині супроводжувалося синтезом ПАР, антимікробна активність яких щодо більшості досліджуваних тест-культур знижувалася у 1,5-2 рази. У той же час дослідження, наведені в [6], показали, що збільшення тривалості культивування N. vaccinii IMB В-7405 на очищеному гліцерині до 7 діб супроводжувалося синтезом ПАР, обидва препарати яких (супернатант, розчин ПАР) руйнували біоплівку $E$. coli IEM-1 на $72-80 \%$ тільки за найнижчих концентрацій (8,75-17,5 мкг/мл). Збільшення концентрації ПАР у таких препаратах супроводжувалось зниженням ступеня руйнування біоплівки до $22-59 \%$. Ці результати ми пояснювали тим, що під час культивування штаму IMB B-7405 3 5-ї по 7-му добу синтезуються не тільки ПАР, а й інші метаболіти, що можуть маскувати їх дію як деструкторів біоплівки.

У зв'язку з цим ми досліджували залежність ступеня руйнування біоплівок за дії ПАР від тривалості культивування штаму ІМВ В-7405.

У табл. 1 наведено дані щодо деструкції біоплівок за наявності ПАР N. vaccinii IMB B-7405, синтезованих на очищеному гліцерині упродовж 5 і 7 діб.

Таблиия 1. Вплив тривалості культивування $N$. vaccinii IMB В-7405 на очищеному гліцерині на здатність ПАР руйнувати бактеріальні та дріжджові біоплівки

\begin{tabular}{|c|c|c|c|c|c|}
\hline \multirow{2}{*}{$\begin{array}{c}\text { Тривалість } \\
\text { культиву- } \\
\text { вання, діб }\end{array}$} & \multirow{2}{*}{ Препарат } & \multirow{2}{*}{$\begin{array}{c}\text { Концентрація } \\
\text { ПАР, мкг/мл }\end{array}$} & $\begin{array}{c}\text { B. subtilis } \\
\text { БТ-2 }\end{array}$ & $\begin{array}{c}\text { Pseudomonas } \\
\text { sp. M-2 }\end{array}$ & $\begin{array}{c}\text { C. albicans } \\
\text { Д-6 }\end{array}$ \\
\hline \multirow{3}{*}{5} & \multirow{2}{*}{ розчин ПАР } & 140 & 57 & 60 & 27 \\
\cline { 3 - 6 } & & 280 & 51 & 54 & 22 \\
\cline { 3 - 6 } & \multirow{2}{*}{ супернатант } & 140 & 53 & 52 & 21 \\
\cline { 3 - 6 } & 280 & 51 & 52 & 20 \\
\hline \multirow{3}{*}{7} & \multirow{2}{*}{ розчин ПАР } & 140 & 36 & 56 & 20 \\
\cline { 3 - 6 } & \multirow{2}{*}{ супернатант } & 280 & 34 & 52 & 18 \\
\cline { 3 - 6 } & & 280 & 29 & 52 & 16 \\
\hline
\end{tabular}

Примітка. Під час визначення ступеня руйнування біоплівки похибка не перевищувала $5 \%$. 
Зазначимо, що на відміну від $E$. coli IEM-1, руйнування біоплівки якої на 70-80\% досягалося за низьких концентрацій ПАР штаму IMВ В-7405 [6], деструкція біоплівок інших бактеріальних тест-культур (B. subtilis БТ-2 і Pseudomonas sp. M-2) на рівні 50-60\% спостерігалася за вищих на порядок концентрацій поверхнево-активних речовин (табл. 1). Причому ступінь руйнування біоплівки Pseudomonas sp. M-2 залишався практично однаковим, незалежно від ступеня очищення препарату (супернатант, розчин ПАР), концентрації ПАР і тривалості вирощування продуцента, у той час як деструкція біоплівки B. subtilis БТ-2 суттєво (на 20-30\%) знижувалася за наявності ПАР, синтезованих упродовж тривалішого часу культивування продуцента.

Схожі закономірності спостерігали щодо деструкції біоплівки C. albicans Д-6, але при цьому ступінь руйнування був більш ніж у два рази нижчим за бактеріальні тест-культури, а різниця між деструкцією цієї біоплівки за наявності ПАР, синтезованих за 5 і 7 діб, була значно меншою і становила всього $4-7 \%$ (див. табл. 1).

На наступному етапі аналізували вплив ПАР, утворюваних N. vaccinii IMB В-7405 на відходах виробництва біодизелю. Оскільки концентрація ПАР, синтезованих на гліцерині різного ступеня очищення, виявилася різною (табл. 2), для досліджень деструкції біоплівок препарати розводили до однакової концентрації ПАР (140-280 мкг/мл, табл. 3).

Таблиця 2. Синтез ПАР $N$. vaccinii ІМВ В-7405 на очищеному гліцерині і відходах виробництва біодизелю

\begin{tabular}{|c|c|c|}
\hline Субстрат для синтезу ПАР & Тривалість культивування, діб & Концентрація ПАР, г/л \\
\hline \multirow{2}{*}{ Очищений гліцерин } & 5 & $2,0 \pm 0,10$ \\
\cline { 2 - 3 } & 7 & $2,2 \pm 0,11$ \\
\hline \multirow{2}{*}{ Відходи виробництва біодизелю } & 5 & $4,4 \pm 0,22$ \\
\cline { 2 - 3 } & 7 & $4,5 \pm 0,23$ \\
\hline
\end{tabular}

Дані, наведені у табл. 3, засвідчують, що ступінь руйнування біоплівок бактеріальних тест-культур за дії супернатантів, одержаних 3 культуральної рідини після вирощування $N$. vaccinii IMB В-7405 на відходах виробництва біодизелю, є дещо нижчим порівняно з використанням розчинів відповідних ПАР, проте (на відміну від культивування на очищеному гліцерині) збільшення тривалості культивування продуцента супроводжувалося утворенням препаратів, за наявності яких деструкція біоплівок підвищувалася практично до показників, встановлених для ПАР, утворюваних упродовж 5 діб на очищеному гліцерині (див. табл. 1). Оскільки концентрація ПАР, синтезованих упродовж 5 і 7 діб на відходах виробництва біодизелю, є практично однаковою (див. табл. 2), можна припустити, що до кінця культивування на цьому субстраті змінюється співвідношення складових комплексу ПАР в результаті їх взаємоперетворень, наприклад, за рахунок глікозилювання чи амінування нейтральних ліпідів.

У той же час ступінь руйнування дріжджової біоплівки практично не залежав від ступеня очищення препарату (супернатант, розчин ПАР), концентрації ПАР і тривалості вирощування продуцента на відходах виробництва біодизелю (див. табл. 3). 
Таблиия 3. Руйнування біоплівок за наявності ПАР, синтезованих $N$. vaccinii IMВ В-7405 на відходах виробництва біодизелю

\begin{tabular}{|c|c|c|c|c|c|c|}
\hline \multirow{2}{*}{$\begin{array}{c}\text { Тривалість } \\
\text { культиву- } \\
\text { вання, діб }\end{array}$} & \multirow{2}{*}{ Препарат } & \multirow{2}{*}{$\begin{array}{c}\text { Концентрація } \\
\text { ПАР, мкг/мл }\end{array}$} & \multicolumn{4}{|c|}{ Руйнування біоплівки, \% } \\
\cline { 4 - 7 } & & & E. coli & $\begin{array}{c}\text { B. subtilis } \\
\text { IEseudomonas } \\
\text { БТ-2 }\end{array}$ & $\begin{array}{c}\text { C. albicans } \\
\text { sp. M-2 }\end{array}$ & Д-6 \\
\hline \multirow{3}{*}{5} & \multirow{2}{*}{ розчин ПАР } & 140 & 40 & 40 & 46 & 24 \\
\cline { 3 - 7 } & \multirow{2}{*}{ супернатант } & 280 & 33 & 32 & 40 & 23 \\
\cline { 3 - 7 } & & 280 & 28 & 30 & 25 & 21 \\
\hline \multirow{3}{*}{7} & \multirow{2}{*}{ розчин ПАР } & 140 & 43 & 55 & 60 & 25 \\
\cline { 3 - 7 } & & 280 & 38 & 53 & 52 & 24 \\
\cline { 3 - 7 } & \multirow{2}{*}{ супернатант } & 140 & 35 & 31 & 50 & 22 \\
\cline { 3 - 7 } & 280 & 27 & 29 & 29 & 20 \\
\hline
\end{tabular}

Примітка. Під час визначення ступеня руйнування біоплівки похибка не перевищувала 5\%.

Зазначимо, що інформація щодо біологічних властивостей мікробних ПАР, синтезованих на промислових відходах, є нечисленною. Разом 3 тим наявні відомості про використання для руйнування біоплівок поверхневоактивних речовин, синтезованих на традиційних субстратах. Порівняння одержаних нами результатів з даними літератури наведено у табл. 4.

Таблиия 4. Порівняльна характеристика різних мікробних ПАР щодо їх впливу на біоплівки

\begin{tabular}{|c|c|c|c|c|c|}
\hline $\begin{array}{l}\text { Субстрат для } \\
\text { синтезу ПАР }\end{array}$ & Продуцент ПАР & $\begin{array}{c}\text { Концентрація } \\
\text { ПАР, мг/мЛ }\end{array}$ & Тест-культури & \begin{tabular}{|c|} 
Ступінь \\
руйнування \\
біоплівки, \% \\
\end{tabular} & Джерело \\
\hline 1 & 2 & 3 & 4 & 5 & 6 \\
\hline \multirow{4}{*}{$\begin{array}{c}\text { Відходи } \\
\text { виробництва } \\
\text { біодизелю }\end{array}$} & \multirow{4}{*}{$\begin{array}{l}\text { Nocardia vaccinii } \\
\text { IMB B-7405 }\end{array}$} & \multirow{4}{*}{0,14} & $\begin{array}{l}\text { Escherichia coli } \\
\text { IEM-1 }\end{array}$ & $28-43$ & \multirow{4}{*}{$\begin{array}{c}\text { Ця } \\
\text { стаття }\end{array}$} \\
\hline & & & $\begin{array}{c}\text { Bacillus subtilis } \\
\text { БТ-2 }\end{array}$ & $26-55$ & \\
\hline & & & $\begin{array}{l}\text { Pseudomonas sp. } \\
\text { M-2 }\end{array}$ & $20-60$ & \\
\hline & & & $\begin{array}{c}\text { Candida albicans } \\
\text { Д-6 }\end{array}$ & $19-25$ & \\
\hline \multirow{2}{*}{$\begin{array}{c}\text { Рафінована } \\
\text { кукурудзяна } \\
\text { олія }\end{array}$} & \multirow[b]{2}{*}{$\begin{array}{l}\text { Corynebacterium } \\
\text { xerosis NS5 }\end{array}$} & \multirow[b]{2}{*}{100} & $\begin{array}{c}\text { Escherichia coli } \\
\text { ATCC } 8739\end{array}$ & 66 & \multirow[b]{2}{*}[11]{} \\
\hline & & & $\begin{array}{c}\text { Pseudomonas } \\
\text { aeruginosa ATCC } \\
9027 \\
\end{array}$ & 30 & \\
\hline $\begin{array}{l}\text { Очищений } \\
\text { гліцерин }\end{array}$ & $\begin{array}{c}\text { Lactobacillus jensenit } \\
25258 \text { та } L . \\
\text { rhamnosus } 7469\end{array}$ & 50 & $\begin{array}{c}\text { Escherichia coli } \\
\text { EC433 }\end{array}$ & 75 & [12] \\
\hline \multirow{3}{*}{$\begin{array}{c}\text { Очищений } \\
\text { гліцерин }\end{array}$} & \multirow{3}{*}{$\begin{array}{c}\text { Enterococcus } \\
\text { faecium MRTL } 9\end{array}$} & \multirow{3}{*}{1,56} & $\begin{array}{c}\text { Escherichia coli } \\
\text { ATCC } 25922\end{array}$ & 41 & \multirow{3}{*}{ [13] } \\
\hline & & & $\begin{array}{c}\text { Pseudomonas } \\
\text { aeruginosa ATCC } \\
15442 \\
\end{array}$ & 40 & \\
\hline & & & $\begin{array}{c}\text { Candida albicans } \\
\text { MTCC } 183 \\
\end{array}$ & 20 & \\
\hline
\end{tabular}




\begin{tabular}{|c|c|c|c|c|c|}
\hline \multicolumn{6}{|c|}{ Продовження табл. 4} \\
\hline 1 & 2 & 3 & 4 & 5 & 6 \\
\hline $\begin{array}{c}\text { Очищений } \\
\text { гліцерин }\end{array}$ & $\begin{array}{c}\text { Candida sphaerica } \\
\text { UCP } 0995\end{array}$ & 10 & $\begin{array}{c}\text { Pseudomonas } \\
\text { aeruginosa } \\
\text { ATCC } 10145\end{array}$ & 80 & {$[14]$} \\
\hline Сахароза & $\begin{array}{c}\text { Bacillus } \\
\text { amyloliquefaciens } \\
\text { AR2 }\end{array}$ & 1 & $\begin{array}{l}\text { Candida albicans } \\
\text { MTCC } 183\end{array}$ & 54 & {$[15]$} \\
\hline $\begin{array}{c}\text { Очищений } \\
\text { гліцерин }\end{array}$ & $\begin{array}{c}\text { Burkholderia } \\
\text { thailandensis E264 }\end{array}$ & \multirow[b]{2}{*}{0,4} & \multirow{2}{*}{$\begin{array}{c}\text { Bacillus subtilis } \\
\text { BBК006 }\end{array}$} & 80 & \multirow[b]{2}{*}[16]{} \\
\hline Глюкоза & $\begin{array}{c}\text { Pseudomonas } \\
\text { aeruginosa ATCC } \\
9027\end{array}$ & & & 60 & \\
\hline
\end{tabular}

Дані табл. 4 засвідчують, що в літературі представлені відомості про руйнування біоплівок умовно патогенних мікроорганізмів за впливу мікробних ПАР, синтезованих на таких субстратах, як очищений гліцерин, вуглеводи та рафінована олія. При цьому відсоток руйнування біоплівок тесткультур є у деяких випадках більший, ніж за наявності ПАР, синтезованих $N$. vaccinii IMB B-7405 на відходах виробництва біодизелю, проте концентрації ПАР, за яких відбувалася деструкція, були на порядки вищими, ніж встановлені нами у пропонованому дослідженні для ПАР штаму IMB В-7405.

Так, наприклад, за дії ПАР Corynebacterium xerosis NS5 у концентрації 100 мг/мл, синтезованих на рафінованій кукурудзяній олії, спостерігали руйнування біоплівки $E$. coli та $P$. aeruginosa на 66 та 30\% відповідно [11]. У разі використання високої (1,56 мг/мл) концентрації ПАР E. faecium MRTL 9, одержаних на очищеному гліцерині, деструкція біоплівок E. coli, P. Aeruginosa та C. albicans становила 41, 40 та 20\% відповідно [13].

\section{Висновок}

Отже, незважаючи на нижчий ступінь деструкції бактеріальних біоплівок за наявності ПАР, синтезованих $N$. vaccinii IMB В-7405 на відходах виробництва біодизелю (порівняно з використанням ПАР, одержаних на очищеному гліцерині), ці показники (руйнування до 50-60\% біоплівок при концентрації ПАР 140 мкг/мл) є порівнянними (а в деяких випадках і перевищують) з визначеними для відомих у світі мікробних поверхнево-активних речовин.

Крім того, одержані нами результати вказують, що заміна очищеного гліцерину в середовищі культивування $N$. vaccinii IMB В-7405 на відходи виробництва біодизелю дає змогу, по-перше, підвищити рентабельність такого виробництва, по-друге, утилізувати токсичні відходи, по-третє, здешевити процес біосинтезу ПАР, по-четверте, одержати цільовий продукт з високою здатністю до руйнування біоплівок умовно патогенних і патогенних мікроорганізмів.

Залежність біологічних властивостей мікробних поверхнево-активних речовин від тривалості процесу і «якості» використовуваного субстрату засвідчують необхідність проведення досліджень 3 впливу умов культивування продуцентів на властивості цільового продукту. 


\section{Лiтература}

1. Maganaa M., Seretia C., Ioannidisa A., Mitchell C. A., Balle A. R., Magiorkinis E., Chatzipanagiotou S., Hamblinh M. R., Hadjifrangiskou M., Tegos G. P. Options and limitations in clinical investigation of bacterial biofilms. Clin. Microbiol. Rev. 2018, 31(3). pii: e00084-16. doi: 10.1128/CMR.00084-16.

2. Jałowiecki Ł., Żur J., Chojniak J., Ejhed H., Płaza G. Properties of antibiotic-resistant bacteria isolated from onsite wastewater treatment plant in relation to biofilm formation. Curr. Microbiol. 2018, 75(5): 639-649. doi: 10.1007/s00284-017-1428-2.

3. van Tilburg Bernardes E., Lewenza S. Reckseidler-Zenteno S. Current research approaches to target biofilm infections. Postdoc J. 2015, 3(6): 36-49.

4. Banat I.M., De Rienzo M.A., Quinn G.A. Microbial biofilms: biosurfactants as antibiofilm agents. Appl. Microbiol. Biotechnol. 2014, 98(24): 9915-9929. doi: 10.1007/s00253-014-6169-6.

5. Garlapati V.K., Shankar U., Budhiraja A. Bioconversion technologies of crude glycerol to value added industrial products. Biotechnol. Rep. (Amst). 2015, 9: 9-14. doi: 10.1016/j.btre.2015.11.002.

6. Pirog T., Nikitiuk L., Kondrashevska K., Kluchka I. Influence of surfactants synthesized under different cultivation conditions of Nocardia vaccinii IMV B-7405 on Escherichia coli IEM-1 biofilm destruction. Scientific Works of NUFT. 2017, 23(2): 23-30. Ukrainian.

7. Pirog T., Shulyakova M., Sofilkanych A., Shevchuk T., Maschenko O. Biosurfactant synthesis by Rhodococcus erythropolis IMV Ac-5017, Acinetobacter calcoaceticus IMV B7241, Nocardia vaccinii IMV B-7405 on byproduct of biodiesel production. Food Bioprod. Proces. 2015, 93(1): 11-18. https://doi.org/10.1016/j.fbp.2013.09.003.

8. Pirog T., Nikitiuk L., Sidor I., Paliichuk O., Petrenko N. Antimicrobial activity of surfactants synthesized by $A$. calcoaceticus IMV B-7241, $R$. erythropolis IMV Ac-5017 and $N$. vaccinii IMV B-7405 on industrial waste. Scientific Works of NUFT. 2017, 23(5, Pt 2): 8-16. doi:10.24263/2225-2924-2017-23-5-2-3. Ukrainian.

9. Gomes M-Z.V., Nitschke M. Evaluation of rhamnolipids surfactants as agents to reduce the adhesion of Staphylococcus aureus to polystyrene surfaces. Lett. Appl. Microbiol. 2012, 49(1): $960-965$.

10. Pirog T., Nikitiuk L., Tymoshuk K. Influence of the duration of cultivation on antimicrobial properties of Nocardia vaccinii IMV B-7405 surfactants. Scientific Works of NUFT. 2016, 22(5): 25-32. Ukrainian.

11. Dalilia D., Aminib M., Faramarzic M. A., Fazelia M. R., Khoshayanda M. R., Samadi N. Isolation and structural characterization of Coryxin, a novel cyclic lipopeptide from Corynebacterium xerosis NS5 having emulsifying and anti-biofilm activity. Colloids Surf. B: Biointerfaces. 2015, 135: 425 - 432. doi: 10.1016/j.colsurfb.2015.07.005.

12. Sambanthamoorthy K., Feng X., Patel R., Patel S., Paranavitana C. Antimicrobial and antibiofilm potential of biosurfactants isolated from lactobacilli against multi-drug-resistant pathogens. BMC Microbiol. 2014, 14:197. doi: 10.1186/1471-2180-14-197.

13. Sharma D., Saharan B. S., Chauhan N., Procha S., Lal S. Isolation and functional characterization of novel biosurfactant produced by Enterococcus faecium. Springerplus. 2015, 4:4. doi: 10.1186/2193-1801-4-4.

14. Padmavathi A. R., Pandian S. K. Antibiofilm activity of biosurfactant producing coral associated bacteria isolated from gulf of mannar. Indian J. Microbiol. 2014, 54(4): 376-382. doi: 10.1007/s12088-014-0474-8.

15. Rautela R., Singh A.K., Shukla A., Cameotra S.S. Lipopeptides from Bacillus strain AR2 inhibits biofilm formation by Candida albicans. Antonie van Leeuwenhoek. 2014, 105(5): 809-821. doi: 10.1007/s10482-014-0135-2

16. De Rienzo M.A.D., Martin P.J. Effect of mono and di-rhamnolipids on biofilms preformed by Bacillus subtilis BBK006. Curr. Microbiol. 2016, 73(2): 183-189. doi: 10.1007/s00284-016-1046-4. 